\title{
EMBRYONIC DEVELOPMENT TIME OF Penilia avirostris DANA, 1852 IN A TROPICAL BAY IN BRAZIL
}

\author{
VALENTIN, J. L. and MARAZZO, A. \\ Laboratório de Zooplâncton, Departamento de Biologia Marinha, Instituto de Biologia, Universidade Federal do \\ Rio de Janeiro, CEP 21949-900, Rio de Janeiro, RJ, Brazil \\ Correspondence to: Jean L. Valentin, Laboratório de Zooplâncton, Departamento de Biologia Marinha, \\ Instituto de Biologia, Universidade Federal do Rio de Janeiro, CEP 21949-900, Rio de Janeiro, RJ, \\ Brazil, e-mail: jlv@biologia.ufrj.br \\ Received May 12, 2003 - Accepted October 10, 2003 - Distributed November 30, 2004
}

(With 1 figure)

\begin{abstract}
Development time of embryos in the brood pouch of the cladoceran Penilia avirostris Dana, 1852, was estimated by collecting zooplankton daily for 15 days in surface water of Guanabara Bay, Brazil. Each day the maturity stage of embryos of 90 parthenogenic females was noted. Total development time (egg to birth) varied from 2 to 3 days, the immature phase (stages I to IV) being generally longer ( 2 days) than intermediate and mature phases (1 day, stages V to XII). Similar results were obtained from Bottrell's equation, which takes water temperature into account.
\end{abstract}

Key words: zooplankton, Cladocera, Penilia avirostris, embryonic development, Guanabara Bay, Brazil.

\section{RESUMO}

\section{Tempo de desenvolvimento dos embriões de Penilia avirostris Dana, 1852, em uma baía tropical do Brasil}

O tempo de desenvolvimento na câmara incubadora dos embriões do cladócero Penilia avirostris Dana, 1852, foi estimado a partir do zooplâncton coletado na água superficial da Baía de Guanabara, Brasil, diariamente, durante 15 dias. A cada dia, foi anotado o estágio de maturidade dos embriões de 90 fêmeas partenogenéticas. O tempo de desenvolvimento total (do ovo até o nascimento) variou de 2 a 3 dias, sendo a fase imatura (estágios I e IV) geralmente mais longa (2 dias) que as fases intermediárias e maturas (1 dia, estágios V a XII). Resultados similares foram obtidos com a equação de Bottrell, que leva em conta a temperatura da água.

Palavras-chave: zooplâncton, Cladocera, Penilia avirostris, desenvolvimento embrionário, baía de Guanabara, Brasil.

\section{INTRODUCTION}

In spite of its high density and important role in trophodynamics, the marine cladoceran Penilia avirostris has been little studied compared to the large number of works on other planktonic crustaceans. This species is cosmopolitan, typically coastal (Onbé, 1974), and may be an important component of the "microbial loop" between bacterioplankton and higher consumers because of its predation on bacterivorous microflagellates (Turner et al., 1988).
Available information on marine cladoceran dynamics mainly stems from observations in temperate waters (Onbé \& Ikeda, 1995; Tang et al., 1995). But this study was carried out in Guanabara Bay (Brazil), a tropical and highly eutrophic bay (Marazzo \& Valentin, 2001), in which recent studies of cladoceran distribution have shown that $P$. avirostris is one of the most abundant mesozooplanktonic components. However, in spite of favorable conditions for spectacular growth (high water temperature and food availability), maximum densities reached by the local $P$. 
avirostris population are much lower than maxima reported from other coastal waters $\left(50.10^{3}\right.$ ind. $\mathrm{m}^{-3}$ in Jamaica, Grahame, 1976; $150.10^{3}$ ind. $\mathrm{m}^{-3}$ in Japan, Onbé, 1974). Different factors may contribute separately or together to the low density of the P. avirostris population in Guanabara Bay. High densities of animals are attained as a result of high embryonic growth rates combined with parthenogenic reproduction. Della Croce \& Bettanin (1965) arbitrarily divided the developmental process of embryos from parthenogenic eggs in the brood chamber into 12 stages, differentiated by changes in shape and progressive appearance of appendages. This division constitutes a useful guide for determining developmental stages in physiological and ecological studies.

This study aimed to estimate the development time of embryos in the brood chamber of parthenogenic females of $P$. avirostris in Guanabara Bay, as an important parameter for studying cladoceran population dynamics in tropical waters.

Zooplankton samples were taken daily from surface waters over a 15-day period (18 April through 2 May 2001). The sampling station (30 m depth) was located in a narrow part of the bay (Fig. 1). Zooplankton samples were taken in triplicate with a conical net $(200 \mu \mathrm{m}$ mesh, $0.5 \mathrm{~m}$ diameter, $2 \mathrm{~m}$ long) provided with a flowmeter. To prevent egg loss, samples were preserved in a chilled sugar (4\%) formaldehyde solution. In the laboratory, young and adult individuals were counted, and 30 females were randomly taken from each sample (a total of 90 females on each day of collection) and cleared in glycerin droplets for 24 hours. Next, the maturity stage of embryos in the brood chamber was noted and classified as "premature" (stages I to IV), "intermediate" (stages V-VIII), and "mature" (stages IX-XII). The percentage of females at each maturity stage was calculated.

During the 15-day study period, temperature and salinity of the surface water were relatively stable, varying respectively from 24.7 to $26.0^{\circ} \mathrm{C}$ and from 31.5 to 34.2. Densities of Penilia avirostris mostly ranged between 200 and 400 ind. $\mathrm{m}^{-3}$, except on three occasions when there were peaks of $1928 \pm$ 248 ind. $\mathrm{m}^{-3}$ (18 April), $1019 \pm 180$ ind. $\mathrm{m}^{-3}$ (23 April), and $638 \pm 118$ ind. $\mathrm{m}^{-3}$ (27 April). The percentage of young individuals in the total population varied from 22 to 45 , and the density of gamogenic individuals was very low $\left(<2\right.$ ind. $\left.\mathrm{m}^{-3}\right)$. Table 1 shows the changes in maturity stage of embryos of the population. There was a time-lag of approximately 2 days between peaks of females bearing embryos in the premature (stages I-IV) and intermediate stages (V-VIII), and just 1 day between peaks of females bearing embryos in the intermediate and mature stages (IX-XII).

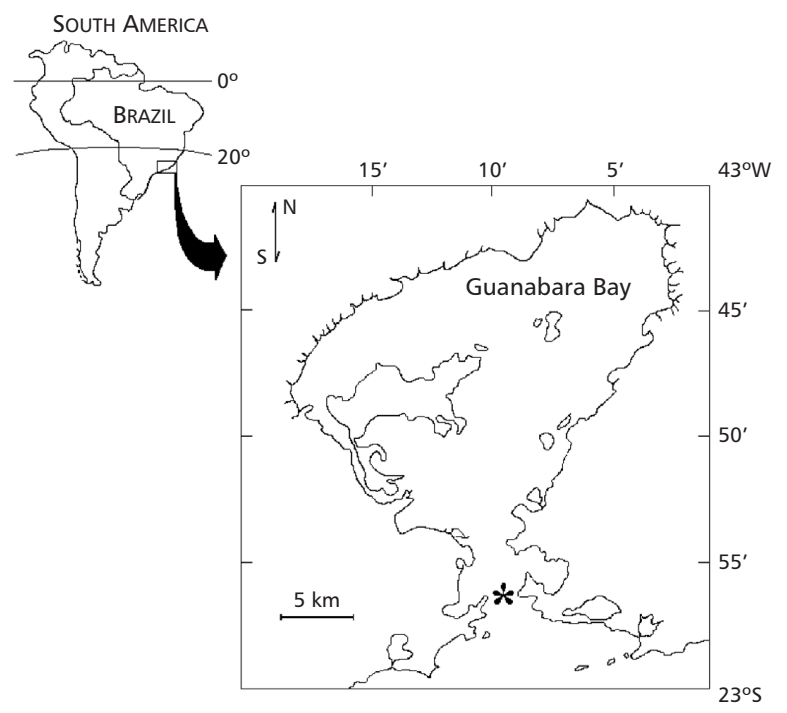

Fig. 1 - Location of the sampling station in Guanabara Bay. 
TABLE 1

Mean values of Penilia avirostris density $\left(\overline{\mathrm{X}}\right.$ ind. $\left.\mathrm{m}^{-3}\right)$, percentage of young individuals $(\% \mathrm{Y})$, percentages of parthenogenic females at successive maturity stages of embryos (I-IV are premature stages, V-VIII are intermediary maturity stages, and IX-XII are mature stages; W/out is percentage of females without embryos), water temperature (T), and salinity (S). (sd is 1 standard deviation.)

\begin{tabular}{|c|c|c|c|c|c|c|c|c|}
\hline \multirow{2}{*}{ Date } & \multirow{2}{*}{$\mathbf{T}$} & \multirow{2}{*}{$\mathbf{S}$} & \multicolumn{2}{|c|}{ P. avirostris } & \multicolumn{4}{|c|}{ Embryo maturity stages $(\%)(*)$} \\
\hline & & & $\bar{X} \pm$ sd & $\% \mathbf{Y}$ & I-IV & V-VIII & IX-XII & W/out \\
\hline $18 / 4 / 01$ & 25.20 & 33.20 & $1928.18 \pm 248.74$ & 32 & 12.5 & 12.5 & 75.0 & 0.0 \\
\hline $19 / 4 / 01$ & 25.40 & 32.42 & $417.91 \pm 21.54$ & 21 & 100.0 & 0.0 & 0.0 & 0.0 \\
\hline $20 / 4 / 01$ & 25.50 & 31.85 & $231.74 \pm 38.40$ & 27 & 72.0 & 0.0 & 28.0 & 0.0 \\
\hline $21 / 4 / 01$ & 24.70 & 32.52 & $148.13 \pm 21.16$ & 41 & 0.0 & 71.0 & 29.0 & 0.0 \\
\hline $22 / 4 / 01$ & 25.10 & 31.98 & $230.13 \pm 50.09$ & 35 & 28.0 & 0.0 & 72.0 & 0.0 \\
\hline $23 / 4 / 01$ & 24.90 & 33.23 & $1019.49 \pm 180.48$ & 35 & 20.0 & 60.0 & 20.0 & 0.0 \\
\hline $24 / 4 / 01$ & 25.40 & 33.31 & $277.97 \pm 41.31$ & 43 & 0.0 & 44.0 & 56.0 & 0.0 \\
\hline $25 / 4 / 01$ & 25.70 & 32.66 & $258.53 \pm 9.18$ & 44 & 61.0 & 16.0 & 23.0 & 0.0 \\
\hline $26 / 4 / 01$ & 25.60 & 33.53 & $279.97 \pm 22.73$ & 34 & 60.0 & 13.0 & 27.0 & 0.0 \\
\hline $27 / 4 / 01$ & 25.90 & 33.54 & $637.91 \pm 117.86$ & 42 & 18.0 & 41.0 & 30.0 & 11.0 \\
\hline $28 / 4 / 01$ & 25.90 & 33.08 & $270.36 \pm 62.37$ & 45 & 12.0 & 12.0 & 62.0 & 14.0 \\
\hline $29 / 4 / 01$ & 25.90 & 33.40 & $269.98 \pm 46.31$ & 39 & 40.0 & 5.0 & 55.0 & 0.0 \\
\hline $30 / 4 / 01$ & 25.40 & 33.91 & $211.10 \pm 73.09$ & 35 & 70.0 & 0.0 & 30.0 & 0.0 \\
\hline $1 / 5 / 01$ & 26.00 & 26.25 & $285.47 \pm 21.91$ & 38 & 20.0 & 50.0 & 20.0 & 10.0 \\
\hline $2 / 5 / 01$ & 26.00 & 33.21 & $212.01 \pm 32.30$ & 42 & 60.0 & 20.0 & 20.0 & 0.0 \\
\hline
\end{tabular}

(*) Gray cells are peaks of percentage indicating changes in the maturity stage.

Daily collections of Penilia avirostris in Guanabara Bay allowed us to visualize the successive maturity stages of embryos during a 15-day period. Under conditions of high temperature $\left(24-25^{\circ} \mathrm{C}\right)$ and typical coastal salinity (32-34), total development time (egg to birth) varied from 2 to 3 days, depending on duration of the premature phase, which could vary from 1 to 2 days. The development time of embryos of $P$. avirostris in Guanabara Bay is similar to that observed in results of Paffenhöfer \& Orcutt (1986), who also recorded a 3-day period for complete embryo development of this species at a $21^{\circ} \mathrm{C}$ temperature. There is a consensus in the literature that temperature is the most important factor governing embryo development time in the brood pouch of parthenogenic females of cladocerans. In some cases, late development stages may also be greatly prolonged because of stress or injury (Egloff et al., 1997). Bottrell (1975) related data for embryo development time $(D)$ of Evadne normanni to water temperature $(T)$ by a second-degree logarithmic polynomial equation: $\log D=0.847(\log T)^{2}-3.609(\log T)+3.796$

When we applied this equation to our data using the minimum $\left(24.7^{\circ} \mathrm{C}\right)$ and maximum $\left(26.0^{\circ} \mathrm{C}\right)$ temperatures observed during the study period in Guanabara Bay, the estimated development times were 2.66 days and 2.43 days respectively. These periods conform to the development times estimated from the field data.

Acknowledgements - This research is part of the PRONEX Project, and was supported by the Conselho Nacional de Desenvolvimento Científico e Tecnológico (CNPq) and the Fundação de Amparo à Pesquisa do Estado do Rio de Janeiro (FAPERJ).

\section{REFERENCES}

BOTTRELL, H. H., 1975, The relationship between temperature and duration of egg development in some epiphytic Cladocera and Copepoda from the River Thames, Reading, with a discussion of temperature functions. Oecologia, 18: 63-84. 
DELLA CROCE, N. \& BETTANIN, S., 1965, Sviluppo embrionale della forma partenogenetica de Penilia avirostris Dana. Cah. Biol. Mar., 6: 269-275.

EGLOFF, D. A., FOFONOFF, P. W. \& ONBÉ, T., 1997, Reproductive biology of marine cladocerans, pp. 79-167. In: J. H. S. Blaxter \& A. J. Southward (eds.), Advances in marine biology. Academic Press.

GRAHAME, J., 1976, Zooplankton of a tropical harbour: the numbers, composition and response to physical factors of zooplankton in Kingston Harbour, Jamaica. J. Exp. Mar. Biol. Ecol., 44: 219-237

MARAZZO, A. \& VALENTIN, J. L., 2001, Spatial and temporal variations of Penilia avirostris and Evadne tergestina (Crustacea, Branchiopoda) in a tropical bay, Brazil. Hydrobiologia, 445: 133-139.
ONBÉ, T., 1974, Studies on the ecology of marine cladocerans. J. Fac. Fish. Anim. Husb. Hiroshima Univ., 13: 83-179 (in Japanese, with abstract in English).

ONBÉ, T. \& IKEDA, T., 1995, Marine cladocerans in Toyama Bay, southern Japan Sea: seasonal occurrence and day-night vertical distributions. J. Plankton Res., 17: 595-609.

PAFFENHÖFER, G. A. \& ORCUTT, J. D., 1986, Feeding, growth and food conversion of the marine cladoceran Penilia avirostris. J. Plankton Res., 8: 741-754.

TANG, K. W., CHEN, Q. C. \& WONG, C. K., 1995, Distribution and biology of marine cladocerans in the coastal waters of southern China. Hydrobiologia, 307: 99-107.

TURNER, J. T., TESTER, P. A. \& FERGUSON, R. L., 1988, The marine cladoceran Penilia avirostris and the "microbial loop" of pelagic food webs. Limnol. Oceanogr., 33: 245-255. 